\title{
Studies on Evaluation, Conservation and Utilization of Kharif Onion Genotypes for Growth and Yield
}

\author{
R. K. Singh ${ }^{1^{*}}$, S. K. Singh ${ }^{2}$ and A. K. Tailor ${ }^{3}$ \\ ${ }^{1}$ Department of Vegetable Science, College of Horticulture, Banda University of \\ Agriculture and Technology, Banda UP \\ ${ }^{2}$ NHRDF, New Delhi \\ ${ }^{3} \mathrm{NHRDF}$, Nashik, Maharashtra, India \\ *Corresponding author
}

\section{Keywords}

Onion, Allium cepa,

Genotypes,

Evaluation,

Utilization of onion

\section{Article Info}

Accepted:

10 March 2020

Available Online:

10 April 2020

\section{A B S T R A C T}

The main onion growing states in India are Maharashtra, Gujarat, Karnataka, Tamil Nadu, Odisha, Madhya Pradesh, Uttar Pradesh, Andhra Pradesh, Bihar and Punjab. It is used as a salad or cooked in various ways in all curies, fried or baked and also used in processed form e.g. flakes powder, paste, crush and pickle, etc. Lack of recommended or released variety of high yielding as well as good keeping quality in the country, it creates price fluctuation during off season arrival period. To meet out the domestic requirement and also to fulfil the export demand, selection of high yielding genotype under different agro climatic condition is necessary. The study conducted during Kharif, 2017 at Nashik revealed that highest gross yield $(259.45 \mathrm{q} / \mathrm{ha})$ and marketable yield $(243.52 \mathrm{q} / \mathrm{ha})$ were recorded in the line L-883. The highest 'A' grade bulbs (41.84 \%) was also recorded in the same line. It is concluded from the study the L- 883 can be utilized for as a Kharif onion variety for higher yield and other traits.

\section{Introduction}

India is second largest producer of onion in the world after China. About 73.23 million tons of onions are produced in the world from 3.65 million ha area. India, being major onion-producing country, produces 20.13 million tons from 1.19 million ha, with a very low productivity of $16.24 \mathrm{t} / \mathrm{ha}$ in comparison to Republic of Korea (64.58 t/ha), USA
(54.47 t/ha), Spain (53.69 t/ha), Netherland (45.80 t/ha), Japan (42.46 t/ha), Germany (41.86 t/ha) and United Kingdom (41.15 t/ha).

About $55-60 \%$ of onion comes from Rabi season and $40-45 \%$ from Kharif and late Kharif season, however, it is to be recognized that India is the largest producer of short day onions globally, which are genetically less yielding compared to the long day types that 
are grown in China. Because of its high export potential, it comes under cash crop apart from vegetable Pandey, (1989). It is predominantly a Rabi season crop and most onion cultivars are sensitive to photo period and thus their range of adoption is limited (Gupta and Singh 2010).

The main onion growing states in India are Maharashtra, Gujarat, Karnataka, Tamil Nadu, Odisha, Madhya Pradesh, Uttar Pradesh, Andhra Pradesh, Bihar and Punjab.

It is used as a salad or cooked in various ways in all curies, fried or baked and also used in processed form e.g. flakes powder, paste, crush and pickle, etc. Lack of recommended or released variety of high yielding as well as good keeping quality in the country, it creates price fluctuation during off season arrival period.

To meet out the domestic requirement and also to fulfill the export demand, selection of high yielding genotype under different agro climatic condition is necessary. In onion, local genotypes play important role in development of new cultivars.

NHRDF, Nashik, collected good number of germplasm and evaluated their performance regarding different attributes. Major emphasis in current onion breeding programs is being placed on mass selection among segregating populations.

Newer methods of onion improvement have been concerned primarily with more efficient means of selection of desirable yield genotypes in segregating populations and selection within their selfed progenies.

To meet out the domestic requirement and also to fulfill the export demand, selection of suitable high yielding varieties for growing under different agro climatic condition is required. Hence under present study a total of 37germplasm along with four checks Agrifound Dark Red, L-883, L-863 and Bheema Dark Red were evaluated to assess their performance for selection of high yielding varieties for Kharif season.

\section{Materials and Methods}

The present investigation was carried out at National Horticultural Research and Development Foundation at Nashik, Maharashtra, during Kharif 2017and 2018. The experiment was laid out in augment with one replications.

The Nashik $\left(20^{\circ} \mathrm{N}\right.$ latitude and $73^{0} \mathrm{E}$ longitudes) is located at altitude of 492.0 meter above mean sea levels. The minimum and maximum temperature and humidity is ranging between $10{ }^{0} \mathrm{C}$ to $40{ }^{\circ} \mathrm{C}$ and $48 \%$ to $80 \%$, respectively, with an annual rain fall around $881 \mathrm{~mm}$.

The soil of the trial was clay loam, medium in organic carbon $(0.58 \%)$, available nitrogen (385.2 kg/ha), phosphorus $(45.13 \mathrm{~kg} / \mathrm{ha})$ and high in available potash (291.2kg/ha). The study comprises 37 diverse onion genotypes along with four checks Agrifound Dark Red, L-863, L-883 and Bheema Dark Red, selected among more than 400 genotypes evaluated at this centre. 45 to 50 days old seedlings of each onion genotypes were transplanted in flat beds during the second week of August in the spacing of $15 \mathrm{~cm} \mathrm{x} 10 \mathrm{~cm}$ in a plot of 3.6 $\mathrm{m} \times 1.8 \mathrm{~m}$ size.

The recommended package of practices was uniformly followed during whole experiment period to raise a successful crop. Randomly selected ten plants from each plot were taken to record the observations on plant establishment $(\%)$, plant height $(\mathrm{cm})$, leaves per plant, neck thickness $(\mathrm{cm})$, equatorial bulb diameter $(\mathrm{cm})$, polar bulb diameter, weight of 
20 bulbs (kg), days for harvesting, doubles $(\%)$, bolters $(\%)$, rotten $\%$, total soluble solid $(\%)$, dry matter content $(\%)$, moisture $(\%)$, gross yield (q/ha), marketable yield (q/ha), \% "A" grade bulbs, \% "B" grade bulbs, \% "C" grade bulbs, $\%$ under sized bulbs, thrips/plant, stemphylium blight intensity.

The pooled data of both the years were analyzed to find out the superior genotypes for development of good quality onion varieties suitable for different agro climatic conditions.

\section{Results and Discussion}

The data of Nashik presented in Table-1 revealed that maximum plant establishment (90.42\%) was recorded in the line L-555 and found at par with all the lines except lines L683, L-704, L780, L-782, L-807, L-810 and L-845.

Highest plant height $(49.73 \mathrm{~cm})$ was recorded in the line L-883 and found at par with the lines L-750, L-753, L-881, L-882, check Agrifound Dark Red, Bheema Dark Red and L-863.

The highest number of leaves per plant (7.60) was recorded in the lines L-883 and L-748 and was at par with the lines L-845, L-862, L866, L-881 and L-882. Thinnest neck (0.94 $\mathrm{cm})$ was recorded in the check L-863 and found at par with the lines L-515, L-555, L562, L-618, L-628, L-682, L-683, L-704, L705, L-770, L-780, L-807, L-810, L-821, L822, L-826, L-844, 1-854, L-862, L-865, L866, L-869, L-880, L-881, L-882, Check Agrifound Dark Red, L-883 and Bheema Dark Red.

The highest equatorial bulb diameter (5.51 $\mathrm{cm})$ and polar bulb diameter $(4.11 \mathrm{~cm})$ were recorded in the line L-883 and found at par with the lines L-888 and check ADR in respect of equatorial bulb diameter and with the lines L-555, L-581, L-748, L-770, L-782, L-810, L822, L-880, L-881, L-882 and check L-863 in respect of polar bulb diameter.

The highest twenty bulb weight $(1.12 \mathrm{~kg})$ was recorded in the check L-883 and found at par with the line L-888 and check Agrifound Dark Red. It is observed that, the plant height, bulb diameter, weight of bulb positively correlated to increase for yield (Singh 1991, Mohanty, 2001 and Singh et. al. 2010).

The lowest doubles $(0.74 \%)$ were noted in the lines L-845, L-854, L-862 and L-888 and found at par with the lines L-515, L-552, L555, L-562, L-581, L0618, L-628, L-682, L683, L-704, L-705, L711, L-780, L-800, L807 and check L-883.

No bolters were noted in the check Agrifound Dark Red, L-883, Bheema Dark Red and L863. Khar et al (1999) reported that incidence of premature bolting was significantly higher in rangda crop compared to Kharif and Rabi crop.

Similarly, dark Red Kharif onion cultivars were observed to be more susceptible for premature bolting than the Light Red Rabi onion cultivar during late Kharif season (Bhonde et al (1992) and Warade et al (1996). No rotted bulbs were recorded in the check Agrifound Dark Red and L-883.

The highest gross yield (259.45 q/ha) and marketable yield $(243.52 \mathrm{q} / \mathrm{ha})$ were recorded in the line L-883.The minimum days to harvest (84 days) was recorded in the line L863.

No significant difference was recorded between the lines in respect of TSS, dry matter and moisture content, however, highest TSS (12.44\%), dry matter (13.82\%) and lowest moisture $(86.18 \%)$ were recorded in the line L-869. 
Table.1 Evaluation and conservation of onion germplasm for Kharif season

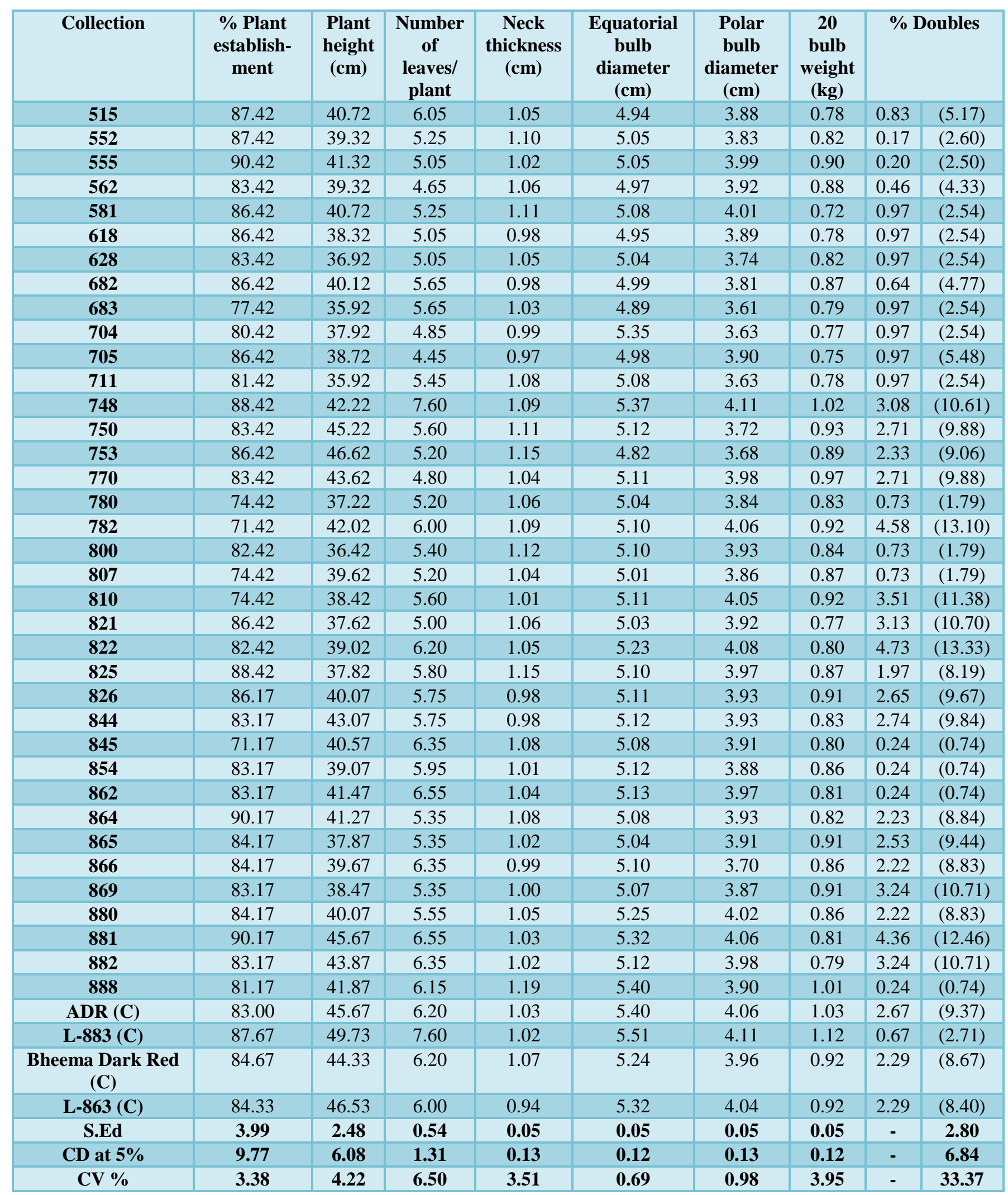




\begin{tabular}{|c|c|c|c|c|c|c|c|c|c|c|}
\hline \multirow{2}{*}{$\begin{array}{c}\text { Collection } \\
515 \\
\end{array}$} & \multicolumn{2}{|c|}{$\%$ Bolters } & \multicolumn{2}{|c|}{ \% Rotten } & \multirow{2}{*}{$\begin{array}{c}\begin{array}{c}\text { Gross } \\
\text { yield }\end{array} \\
\text { (q/ha) } \\
182.32\end{array}$} & \multirow{2}{*}{$\begin{array}{c}\text { Market- } \\
\text { able yield } \\
\text { (q/ha) }\end{array}$} & \multirow{2}{*}{$\begin{array}{c}\begin{array}{c}\text { Days } \\
\text { to } \\
\text { harvest }\end{array} \\
97\end{array}$} & \multirow{2}{*}{$\begin{array}{c}\% \\
\text { TSS } \\
11.36\end{array}$} & \multirow{2}{*}{$\begin{array}{c}\% \text { Dry } \\
\text { matter }\end{array}$} & \multirow{2}{*}{$\begin{array}{c}\begin{array}{c}\% \\
\text { Moisture }\end{array} \\
87.44 \\
\end{array}$} \\
\hline & 0.16 & $(0.94)$ & 0.08 & $(0.47)$ & & & & & & \\
\hline 552 & 0.16 & (0.94) & 0.08 & $(0.47)$ & 190.42 & 181.30 & 102 & 10.96 & 12.33 & 87.67 \\
\hline 555 & 0.16 & $(0.94)$ & 0.08 & $(0.47)$ & 172.36 & 169.72 & 99 & 11.32 & 12.71 & 87.29 \\
\hline 562 & 0.16 & $(0.94)$ & 0.08 & $(0.47)$ & 224.48 & 211.06 & 102 & 11.84 & 13.21 & 86.79 \\
\hline 581 & 1.45 & (6.36) & 0.08 & $(0.47)$ & 164.96 & 144.26 & 99 & 11.16 & 12.52 & 87.48 \\
\hline 618 & 0.16 & $(0.94)$ & 0.08 & $(0.47)$ & 174.22 & 162.78 & 104 & 11.56 & 12.91 & 87.09 \\
\hline 628 & 0.16 & $(0.94)$ & 0.08 & $(0.47)$ & 183.48 & 158.15 & 103 & 11.24 & 12.66 & 87.34 \\
\hline 682 & 1.45 & (6.36) & 1.53 & $(6.83)$ & 192.73 & 172.04 & 103 & 11.36 & 12.72 & 87.28 \\
\hline 683 & 0.16 & $(0.94)$ & 0.08 & $(0.47)$ & 185.79 & 167.41 & 102 & 11.56 & 12.92 & 87.08 \\
\hline 704 & 0.16 & $(0.94)$ & 0.08 & $(0.47)$ & 188.77 & 175.34 & 96 & 12.32 & 13.75 & 86.25 \\
\hline 705 & 0.16 & $(0.94)$ & 0.08 & $(0.47)$ & 195.51 & 181.30 & 96 & 11.20 & 12.42 & 87.58 \\
\hline 711 & 0.16 & $(0.94)$ & 0.08 & $(0.47)$ & 192.73 & 169.26 & 102 & 11.56 & 12.92 & 87.09 \\
\hline 748 & 0.08 & $(0.47)$ & 0.08 & $(0.47)$ & 234.68 & 221.15 & 96 & 11.32 & 12.72 & 87.28 \\
\hline 750 & 0.08 & $(0.47)$ & 0.08 & $(0.47)$ & 184.68 & 171.15 & 91 & 11.88 & 13.19 & 86.81 \\
\hline 753 & 1.68 & (7.74) & 1.52 & $(6.80)$ & 190.70 & 179.49 & 102 & 11.32 & 12.74 & 87.26 \\
\hline 770 & 0.08 & $(0.47)$ & 0.08 & $(0.47)$ & 181.90 & 168.37 & 102 & 11.44 & 12.82 & 87.18 \\
\hline 780 & 0.08 & $(0.47)$ & 0.08 & $(0.47)$ & 183.76 & 171.15 & 103 & 11.60 & 12.29 & 87.01 \\
\hline 782 & 0.08 & $(0.47)$ & 0.08 & $(0.47)$ & 174.50 & 165.60 & 99 & 11.28 & 12.46 & 87.40 \\
\hline 800 & 0.08 & $(0.47)$ & 0.08 & $(0.47)$ & 187.46 & 171.15 & 102 & 12.08 & 13.55 & 86.45 \\
\hline 807 & 0.08 & $(0.47)$ & 0.08 & $(0.47)$ & 193.01 & 167.45 & 102 & 11.92 & 13.62 & 86.38 \\
\hline 810 & 0.08 & $(0.47)$ & 0.08 & $(0.47)$ & 213.85 & 200.32 & 97 & 10.96 & 12.32 & 87.68 \\
\hline 821 & 0.08 & $(0.47)$ & 0.08 & $(0.47)$ & 179.13 & 171.15 & 99 & 11.40 & 12.82 & 87.18 \\
\hline 822 & 2.08 & (8.60) & 1.92 & (7.66) & 187.46 & 173.93 & 98 & 11.56 & 12.29 & 87.08 \\
\hline 825 & 0.08 & $(0.47)$ & 0.08 & 0.47 & 191.16 & 184.12 & 103 & 11.88 & 13.23 & 86.77 \\
\hline 826 & 0.08 & $(0.47)$ & 0.16 & $(0.94)$ & 201.07 & 184.36 & 103 & 11.64 & 12.89 & 87.11 \\
\hline 844 & 0.08 & $(0.47)$ & 0.16 & $(0.94)$ & 187.18 & 173.94 & 103 & 11.40 & 12.82 & 87.18 \\
\hline 845 & 0.08 & $(0.47)$ & 0.16 & $(0.94)$ & 183.71 & 167.00 & 103 & 11.28 & 12.52 & 87.48 \\
\hline 854 & 0.08 & $(0.47)$ & 0.16 & $(0.94)$ & 173.78 & 159.06 & 98 & 11.44 & 12.62 & 87.38 \\
\hline 862 & 0.08 & $(0.47)$ & 0.16 & $(0.94)$ & 185.69 & 170.96 & 103 & 11.68 & 13.00 & 87.00 \\
\hline 864 & 0.74 & (5.14) & 0.16 & $(0.94)$ & 191.64 & 180.89 & 96 & 9.88 & 11.32 & 88.68 \\
\hline 865 & 0.08 & $(0.47)$ & 0.16 & $(0.94)$ & 182.64 & 171.27 & 97 & 11.92 & 13.42 & 86.58 \\
\hline 866 & 2.06 & $(8.56)$ & 0.16 & $(0.94)$ & 192.59 & 178.11 & 96 & 12.08 & 13.62 & 86.38 \\
\hline 869 & 0.08 & $(0.47)$ & 1.16 & (6.68) & 188.15 & 172.55 & 102 & 12.44 & 13.82 & 86.18 \\
\hline 880 & 0.08 & $(0.47)$ & 0.16 & $(0.94)$ & 217.04 & 203.11 & 98 & 11.48 & 12.88 & 87.12 \\
\hline 881 & 0.08 & $(0.47)$ & 0.16 & $(0.94)$ & 182.16 & 170.08 & 102 & 11.64 & 13.01 & 86.99 \\
\hline 882 & 0.08 & $(0.47)$ & 0.16 & $(0.94)$ & 186.48 & 167.00 & 95 & 11.24 & 12.71 & 87.29 \\
\hline 888 & 0.08 & $(0.47)$ & 0.16 & $(0.94)$ & 234.63 & 220.24 & 88 & 11.24 & 12.66 & 87.34 \\
\hline $\operatorname{ADR}(\mathbf{C})$ & 0.00 & - & 0.00 & - & 238.33 & 224.07 & 96 & 11.88 & 13.41 & 86.59 \\
\hline $\mathrm{L-883}(\mathrm{C})$ & 0.00 & - & 0.00 & - & 259.45 & 243.52 & 87 & 11.28 & 12.78 & 87.22 \\
\hline $\begin{array}{l}\text { Bheema Dark Red } \\
\text { (C) }\end{array}$ & 0.00 & - & 0.32 & $(1.88)$ & 223.15 & 211.11 & 96 & 11.36 & 12.71 & 87.29 \\
\hline L-863 (C) & 0.32 & (1.88) & 0.32 & (1.88) & 230.56 & 219.81 & 84 & 11.88 & 13.63 & 86.37 \\
\hline S.Ed & - & 2.31 & - & 3.52 & 3.42 & 3.09 & 0.82 & 0.00 & 0.00 & 0.00 \\
\hline CD at $5 \%$ & - & 5.64 & - & 8.62 & 8.36 & 7.56 & 2.00 & 0.00 & 0.00 & 0.00 \\
\hline CV \% & - & 165.09 & - & 307.20 & 1.19 & 1.16 & 0.59 & 0.00 & 0.00 & 0.00 \\
\hline
\end{tabular}




\begin{tabular}{|c|c|c|c|c|c|c|c|c|c|c|}
\hline Collection & $\begin{array}{c}\% \\
\text { AGB }\end{array}$ & $\begin{array}{c}\% \\
\text { BGB }\end{array}$ & $\begin{array}{c}\% \\
\text { CGB }\end{array}$ & $\begin{array}{c}\% \\
\text { USB }\end{array}$ & \multicolumn{2}{|c|}{ Thrips/plant } & \multicolumn{2}{|c|}{$\begin{array}{l}\text { \% thrips } \\
\text { incidence }\end{array}$} & \multicolumn{2}{|c|}{ PDI of SB } \\
\hline 515 & 0.36 & 44.41 & 49.15 & 6.78 & 20.43 & $(4.59)$ & 100.00 & $(10.02)$ & 10.15 & $(18.45)$ \\
\hline 552 & 0.36 & 44.70 & 47.05 & 8.60 & 19.03 & $(4.43)$ & 100.00 & $(10.02)$ & 15.75 & $(23.35)$ \\
\hline 555 & 0.36 & 41.85 & 51.80 & 6.69 & 20.13 & $(4.55)$ & 100.00 & $(10.02)$ & 12.55 & $(20.67)$ \\
\hline 562 & 22.50 & 52.13 & 19.22 & 6.14 & 20.83 & $(4.63)$ & 100.00 & $(10.02)$ & 10.95 & (19.21) \\
\hline 581 & 0.36 & 58.76 & 36.13 & 5.45 & 22.43 & $(4.81)$ & 100.00 & (10.02) & 14.95 & (22.70) \\
\hline 618 & 0.36 & 66.83 & 29.68 & 3.84 & 19.63 & $(4.50)$ & 100.00 & $(10.02)$ & 18.15 & $(25.20)$ \\
\hline 628 & 0.36 & 64.03 & 33.98 & 2.33 & 20.53 & $(4.60)$ & 100.00 & (10.02) & 14.95 & (22.70) \\
\hline 682 & 0.36 & 50.70 & 45.81 & 3.84 & 20.03 & (4.54) & 100.00 & $(10.02)$ & 14.15 & (22.04) \\
\hline 683 & 0.36 & 60.16 & 35.79 & 4.41 & 20.53 & $(4.60)$ & 100.00 & $(10.02)$ & 16.55 & (23.98) \\
\hline 704 & 0.36 & 54.43 & 43.93 & 1.99 & 22.59 & $(4.82)$ & 100.00 & (10.02) & 15.75 & (23.35) \\
\hline 705 & 0.36 & 63.81 & 35.60 & 0.94 & 22.83 & $(4.85)$ & 100.00 & (10.02) & 14.95 & $(22.70)$ \\
\hline 711 & 0.36 & 55.87 & 42.03 & 2.45 & 20.53 & $(4.60)$ & 100.00 & (10.02) & 12.55 & (20.67) \\
\hline 748 & 39.70 & 52.18 & 6.16 & 1.96 & 15.68 & $(4.03)$ & 100.00 & $(10.02)$ & 11.30 & (19.71) \\
\hline 750 & 0.88 & 59.05 & 37.31 & 2.76 & 17.58 & $(4.25)$ & 100.00 & (10.02) & 9.70 & (18.34) \\
\hline 753 & 0.88 & 51.45 & 43.69 & 3.98 & 16.48 & $(4.12)$ & 100.00 & $(10.02)$ & 12.10 & (20.37) \\
\hline 770 & 0.88 & 48.15 & 44.24 & 6.72 & 17.28 & $(4.21)$ & 100.00 & (10.02) & 15.30 & $(22.87)$ \\
\hline 780 & 0.88 & 54.21 & 40.43 & 4.48 & 18.48 & $(4.35)$ & 100.00 & $(10.02)$ & 12.30 & $(20.53)$ \\
\hline 782 & 0.88 & 64.03 & 30.46 & 4.63 & 17.68 & $(4.26)$ & 100.00 & $(10.02)$ & 15.30 & $(22.87)$ \\
\hline 800 & 0.88 & 56.65 & 37.69 & 4.78 & 15.78 & $(4.04)$ & 100.00 & $(10.02)$ & 12.90 & $(21.02)$ \\
\hline 807 & 0.88 & 65.32 & 29.32 & 4.48 & 15.08 & $(3.96)$ & 100.00 & (10.02) & 10.50 & (19.03) \\
\hline 810 & 20.32 & 48.65 & 24.69 & 6.34 & 16.68 & $(4.14)$ & 100.00 & $(10.02)$ & 10.50 & (19.03) \\
\hline 821 & 0.88 & 53.05 & 35.69 & 10.38 & 16.68 & $(4.14)$ & 100.00 & $(10.02)$ & 12.90 & $(21.02)$ \\
\hline 822 & 0.88 & 53.65 & 40.69 & 4.78 & 17.08 & $(4.19)$ & 100.00 & $(10.02)$ & 12.90 & $(21.02)$ \\
\hline 825 & 0.88 & 57.66 & 37.58 & 3.89 & 16.18 & $(4.09)$ & 100.00 & $(10.02)$ & 9.70 & (18.34) \\
\hline 826 & 0.52 & 66.92 & 29.77 & 3.82 & 16.48 & $(4.12)$ & 100.00 & $(10.02)$ & 19.35 & (26.33) \\
\hline 844 & 0.52 & 63.15 & 34.65 & 2.71 & 18.28 & $(4.33)$ & 100.00 & $(10.02)$ & 12.15 & $(20.34)$ \\
\hline 845 & 0.52 & 59.47 & 34.94 & 6.09 & 18.78 & $(4.39)$ & 100.00 & (10.02) & 18.55 & $(25.73)$ \\
\hline 854 & 0.52 & 59.22 & 35.36 & 5.92 & 19.98 & $(4.53)$ & 100.00 & $(10.02)$ & 13.75 & $(21.80)$ \\
\hline 862 & 0.52 & 63.51 & 35.36 & 1.64 & 20.98 & $(4.64)$ & 100.00 & $(10.02)$ & 19.35 & $(26.33)$ \\
\hline 864 & 0.52 & 54.29 & 40.71 & 5.51 & 18.18 & $(4.32)$ & 100.00 & $(10.02)$ & 13.75 & $(21.80)$ \\
\hline 865 & 0.52 & 54.85 & 36.29 & 9.37 & 19.98 & $(4.53)$ & 100.00 & $(10.02)$ & 13.75 & $(21.80)$ \\
\hline 866 & 0.52 & 66.00 & 32.32 & 2.19 & 18.98 & $(4.41)$ & 100.00 & $(10.02)$ & 12.15 & $(20.34)$ \\
\hline 869 & 0.52 & 69.65 & 27.65 & 3.21 & 19.48 & $(4.47)$ & 100.00 & $(10.02)$ & 16.35 & $(23.99)$ \\
\hline 880 & 19.28 & 51.15 & 27.37 & 2.19 & 17.98 & $(4.30)$ & 100.00 & $(10.02)$ & 19.35 & $(26.33)$ \\
\hline 881 & 0.52 & 57.35 & 37.79 & 5.36 & 18.48 & $(4.36)$ & 100.00 & $(10.02)$ & 16.95 & $(24.48)$ \\
\hline 882 & 0.52 & 61.65 & 35.65 & 3.21 & 18.78 & $(4.39)$ & 100.00 & $(10.02)$ & 14.55 & $(22.49)$ \\
\hline 888 & 16.57 & 44.24 & 34.69 & 4.48 & 18.88 & $(4.40)$ & 100.00 & $(10.02)$ & 12.15 & $(20.34)$ \\
\hline $\operatorname{ADR}(\mathbf{C})$ & 34.43 & 49.80 & 13.45 & 2.32 & 17.07 & $(4.19)$ & 100.00 & $(10.02)$ & 14.40 & (22.26) \\
\hline $\mathrm{L}-883(\mathrm{C})$ & 41.84 & 43.78 & 11.86 & 2.51 & 16.33 & $(4.10)$ & 100.00 & $(10.02)$ & 13.60 & $(21.54)$ \\
\hline Bheema Dark Red (C) & 24.94 & 47.54 & 22.93 & 4.59 & 19.97 & $(4.52)$ & 100.00 & $(10.02)$ & 13.13 & $(21.19)$ \\
\hline $\operatorname{L-863}(C)$ & 31.59 & 46.07 & 19.07 & 3.27 & 18.27 & $(4.32)$ & 100.00 & (10.02) & 13.87 & (21.67) \\
\hline S.Ed & 4.24 & 7.96 & 7.93 & 2.02 & - & 0.33 & - & 0.00 & - & 3.58 \\
\hline CD at $5 \%$ & 10.38 & 19.49 & 19.41 & 4.95 & - & 0.80 & - & 0.00 & - & 8.77 \\
\hline CV \% & 28.45 & 10.40 & 18.05 & 33.96 & - & 5.27 & - & 0.00 & - & 11.60 \\
\hline
\end{tabular}

Note- Data in the parenthesis shows arcsin transformed values 
The highest " $A$ " grade bulb (41.84\%) were recorded in line L-883 and found at par with the lines L-748, Check Agrifound Dark Red, and L-863. The highest " $\mathrm{B}$ " grade bulb were recorded in the line L-869 (69.65\%) and found at par with all of the lines except L515, L-552, L-555, L-770, L-810, L-888 and check Agrifound Dark Red, L-883, Bheema Dark Red and L-863.

The lowest " $C$ " grade bulb $(6.16 \%)$ were recorded in the line L-748 and found at par with the lines L-562, L-810, Check Agrifound Dark Red, L-883, Bheema Dark Red and L863. The highest average bulb weight (112.33 gm) was recorded in the check L-883 and found at par with the line L-748 and check ADR. The minimum under sized bulb (0.94 $\%$ ) were recorded in the line L-705 and found at par with all of the line except L-515, L-552, L-555, L-562 L-770, L-810, L-821 and L854. The lowest thrips per plant (3.96) were recorded in the line $\mathrm{L}-807$ and found at par with all the lines except L-581, L-704 and L711. The incidence of thrips was found $100 \%$ in all the lines. The lowest disease intensity of stemphylium blight $(9.70 \%)$ was recorded in the line L-750 and L-825. The lowest incidence of stemphylium blight $(60 \%)$ was recorded in the check L-883 and found at par with all the line.

\section{References}

Bhonde, S. R., Srivastava, K. J. and Pandey, U. B. (1992). Evaluation of varieties growing 'rangda' crop of onion (Allium cepa L) in Nashik area of Maharashtra. Maharashtra J. Hort. 6(2): 39-42.

Khar, A. K., Devi, A. and Lawande, K. E. (1999). Performance studies in resealed onion varieties. Ann. Rep. NRC for Onion and Garlic 12-15pp

Mohanty, B.K.(2001). Genetic variability, inter relationship and path analysis in onion. Journal of Tropical Aquaculture 39:17-20.

Pandey, U. B. (1989). Onion (Allium cepa L.)Indian Horticulture33-34:58-62

Singh, L, Singh, S. P. and Mishra, P. K. (1991). Evaluation of onion varieties at Karnal. NHRDF News Letter VI (3): 3-4

Singh, R. K., Dubey, B. K. Bhonde, S. R. and Gupta, R. P. (2010).Estimates of genetic variability, heritability and correlation in red onion (Allium cepa L.) advance lines. Journal of Indian Agriculture Science, 80 (2): 160-163

Warade, S. D., Desale, S. B. and Shinde, K. G. (1996). Evaluation of onion cultivars for yield and storability for ragada season. J. Maharashtra Agric. Univ. 21(1): 48-49.

\section{How to cite this article:}

Singh, R. K., S. K. Singh and Tailor; A. K. 2020. Studies on Evaluation, Conservation and Utilization of Kharif Onion Genotypes for Growth and Yield. Int.J.Curr.Microbiol.App.Sci. 9(04): 877-883. doi: https://doi.org/10.20546/ijcmas.2020.904.105 